\title{
SYNTHESIS, CHARACTERIZATION, AND EVALUATION OF ANTIOXIDANT AND ANTIMICROBIAL ACTIVITY OF THREE NOVEL N-HETEROAROMATIC HYDRAZONYL-THIAZOLES
}

Sanja B. Kokanov ${ }^{1}$, Milan Nikolić1, Irena Novaković², Tamara R. Todorović1, Nenad R. Filipovićc ${ }^{, *}$

${ }^{1}$ University of Belgrade, Faculty of Chemistry, Belgrade, Serbia

2University of Belgrade, Institute of Chemistry, Technology and Metallurgy, Belgrade, Serbia

3 University of Belgrade, Faculty of Agriculture, Belgrade, Serbia

(Thiazolyl-2-yl)hydrazones (THs) are a group of organic compounds containing both hydrazone and 1,3-thiazole pharmacophores present in many approved drugs. They have been investigated greatly in recent years due to potent anticancer, antibacterial, antifungal, antituberculosis, anti-inflammatory, and antiparasitic activities. In this study, one pyridine-based and two quinoline-based, novel THs were synthesized and characterized by elemental analysis, Fourier-transform infrared spectroscopy (FTIR), and nuclear magnetic resonance spectroscopy (NMR). The antimicrobial activity of the compounds was tested against five Gram-positive and five Gram-negative bacteria, as well as against three fungi. The antioxidant capacity of the compounds was tested in six antioxidative assays. The results showed that quinoline-based THs were more active against tested Gram-negative bacteria and fungi strains than pyridine-based compounds. All the compounds showed excellent antioxidative activity comparable to or greater than the used standards (vitamin $\mathrm{C}$ and Trolox). Absorption, distribution, metabolism, excretion, and toxicity (ADMET) parameters were calculated in-silico. Results pointed to promising good pharmacokinetics profiles of investigated compounds, especially 2-quinoline carboxaldehyde-based compound, which can be a lead drug candidate.
(ORIGINAL SCIENTIFIC PAPER) UDC 547.556.9+547.78:579.8 DOI $10.5937 /$ savteh2102014K

Keywords: Hydrazones, thiazoles, antibacterial activity, antifungal activity, antioxidative capacity, ADMET.

\section{Introduction}

1,3-Thiazole is a well-established pharmacophore in medicinal chemistry. This heteroaromatic ring is present in many natural products, such as vitamin B1 [1], epothilones (a class of potential cancer drugs) [2], and luciferin (the firefly compound) [3]. Its derivatives show a wide range of biological activities, such as analgesic, antibacterial, anticancer, antiallergic, antihypertensive, antiinflammatory, antimalarial, antifungal, antipsychotic, and antioxidant activity [4]. Currently, there are 23 drugs<smiles>Cc1nc(NC(=O)N2CCCC2C(N)=O)sc1-c1ccnc(C(C)(C)C)c1</smiles>

Alpelisib<smiles>COc1c(-c2sc(NC(=O)c3cc(Cl)c(/C=C(\C)C(=O)O)c(Cl)c3)nc2C)cccc1[C@@H](C)OC</smiles>

Luctirombipag

Figure 1 Structures of some of the FDA approved drugs with thiazole and hydrazone pharmacophores based on thiazole ring approved by The Food and Drug Administration (FDA) agency, which is much more than for any other related 5-membered heterocycle [1]. Hydrazone pharmacophore is also one important fragment in medicinal chemistry. At the moment, there are six hydrazone-based drugs approved by FDA, while at least ten drugs containing hydrazone pharmacophore are under clinical trials [5]. Examples of approved drugs containing thiazole or hydrazone pharmacophore are depicted in Figure 1.<smiles>CC1CS(=O)(=O)CCN1/N=C/c1ccc([N+](=O)[O-])o1</smiles>

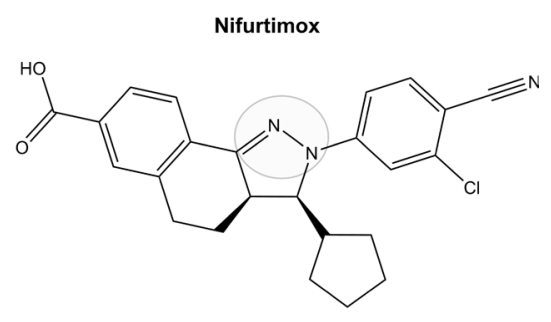

PF-03882845

*Author address: Nenad R. Filipović, University of Belgrade, Faculty of Agriculture,

Nemanjina 6, 11000 Belgrade, Republic of Serbia

e-mail: nenadf@agrif.bg.ac.rs nenadf.chem@gmail.com

The manuscript received: September, 24, 2021.

Paper accepted: September, 30, 2021. 
(Thiazolyl-2-yl)hydrazones (THs) are compounds containing both 1,3-thiazole and hydrazone pharmacophores. THs can be obtained by two-step process. The first step is a simple condensation reaction of thiosemicarbazide and aldehyde/ketone, in which thiosemicarbazone is formed. In the second step, obtained thiosemicarbazone reacts with a-bromoketone to form a thiazole ring and elimination of $\mathrm{HBr}$ (Figure 2). The biological activity of various THs has been investigated to a great extent in recent years. Various THs showed promising anticancer, antibacterial,<smiles>[R]C([R])=O</smiles>

Aldehyde $\mathrm{R}_{1}=\mathrm{H}, \mathrm{R}_{2}=$ alkyl/aryl Ketone $\mathrm{R}_{1}, \mathrm{R}_{2}=$ alkyl/aryl antifungal, antituberculosis, anti-inflammatory, and antiparasitic activities and potential to be used for the treatment of Parkinson's disease and type-2 diabetes mellitus [6]. Inhibitory properties of THs have been experimentally confirmed for some of the enzymes which are recognized as important targets in medicinal chemistry, such as $\alpha$-amylase, $\alpha$-glucosidase, monoamine oxidase $A / B$, acetylcholinesterase, tissue-nonspecific alkaline phosphatase, intestinal alkaline phosphatase, $\beta$-glucuronidase, and ecto-5'-nucleotidase [6].<smiles>[R]C([R])=NN([R9])C(N)=S</smiles>

Thiosemicarbazone

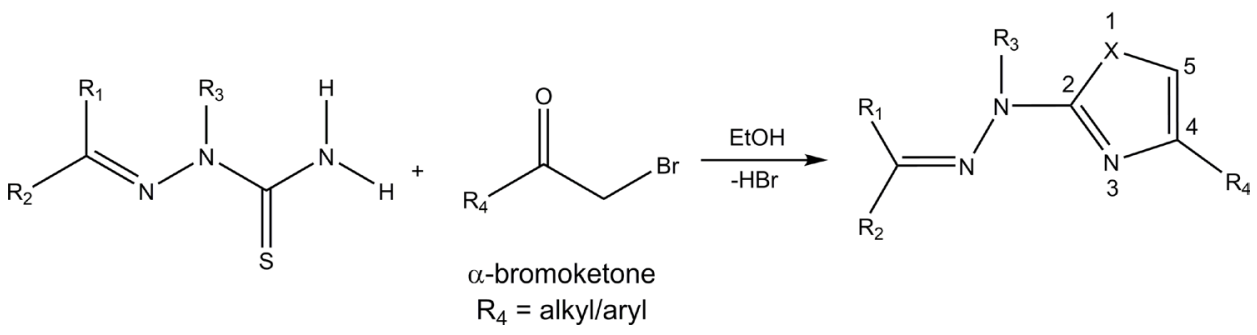

Figure 2 Two-step reaction procedure for preparation of THs

In the present study, three novel $\mathrm{N}$-heteroaromatic THs, (E)-2-(2-(pyridin-2-ylmethylene)hydrazinyl)thiazole4-carboxylic acid (1), (E)-2-(2-(quinolin-2-ylmethylene) hydrazinyl)thiazole-4-carboxylic acid (2) and (E)-2-(2((8-hydroxyquinolin-2-yl)methylene)hydrazinyl)thiazole4-carboxylic acid (3) were synthesized and characterized by elemental analysis, Fourier transform infrared spectroscopy (FTIR) and nuclear magnetic resonance spectroscopy (NMR). Antimicrobial activity of 1-3 was tested against five Gram-negative and five Gram-positive bacteria, as well as against three fungi strains. Additionally, their antioxidant activity was evaluated in six antioxidant assays. In addition, absorption, distribution, metabolism, excretion, and toxicity (ADMET) parameters were calculated in-silico.

\section{Experimental}

Reagents and instrumentation:

Thiosemicarbazide, 2-formylpyridine, and 2-quinolinecarboxaldehyde were obtained from Acros Organics. 8-Hydroxyquinoline-2-carboxaldehyde and bromopyruvic acid were obtained from Maybridge. 2,2'-Azino-bis(3ethylbenzothiazoline-6-sulfonic acid) diammonium salt (ABTS), diphenyl-1-picrylhydrazyl (DPPH), 2,2'-azobis(2methylpropionamidine) dihydrochloride (AAPH), fluo- rescein sodium salt, sodium phosphate, ammonium molybdate, ( $( \pm)$-6-hydroxy-2,5,7,8-tetramethylchromane2-carboxylic acid (Trolox) and vitamin C were obtained from Sigma-Aldrich. All solvents (reagent grade) were obtained from commercial suppliers and used without further purification.

Elemental analyses ( $\mathrm{C}, \mathrm{H}, \mathrm{N}, \mathrm{S})$ were performed by the standard micromethods using the ELEMENTAR Vario EL III CHNS/O analyzer. FTIR spectra were recorded on a Thermo Scientific Nicolet 6700 FT-IR spectrometer by the Attenuated Total Reflection (ATR) technique in the region 4000-400 $\mathrm{cm}^{-1}$. Abbreviations used for FTIR spectra: vs, very strong; $s$, strong; $m$, medium; $w$, weak, vw very weak. The NMR spectra were recorded on a Bruker Avance 500 equipped with broad-band direct probe at room temperature in DMSO- $d_{6}$. Chemical shifts are given on $\delta$ scale relative to tetramethylsilane as internal standard for ${ }^{1} \mathrm{H}$ and ${ }^{13} \mathrm{C}$. Abbreviations used for NMR spectra: s, singlet; $\mathrm{d}$, doublet; $\mathrm{t}$, triplet; dd, double of doublets; $\mathrm{dt}$, double of triplets, m, multiplet. In the UV-Vis region, absorbance was measured on a BioTek's PowerWave XS absorbance microplate reader, while fluorescence was measured on a FluoroMax-4 HORIBA Jobin Yvon. 
Synthesis of thiosemicarbazone precursors:

2-Formylpyridine thiosemicarbazone, 2-quinolinecarboxaldehyde thiosemicarbazone, and 8-hydroxyquinoline2-carboxaldehyde thisemicarbazone were synthesized according to the literature protocol by the condensation reaction of the corresponding aldehyde and thiosemicarbazide by the mole ratio 1:1 [7-9]. Elemental analyses of the obtained thiosemicarbazones were within $\pm 0.4 \%$, confirming $>95 \%$ purity.

Synthesis of (E)-2-(2-(pyridin-2-ylmethylene)hydrazinyl)thiazole-4-carboxylic acid (1):

Solid bromopyruvic acid $(0.09 \mathrm{~g}, 0.55 \mathrm{mmol})$ was added.into the suspension of 2-formylpyridine thiosemicarbazone $(0.10 \mathrm{~g}, 0.55 \mathrm{mmol})$ in a mixture of water and ethanol $(20 \mathrm{~mL}, 3: 1, V /$ ). The reaction mixture was stirred for 24 $\mathrm{h}$ at room temperature. The yellow product was filtered off and washed with cold water. The pure product was obtained by vapour diffusion of ethanol into DMSO solution of the crude product. Yield: $0.102 \mathrm{~g}$ (74 \%). Anal. Calcd for $\mathrm{C}_{10} \mathrm{H}_{8} \mathrm{~N}_{4} \mathrm{O}_{2} \mathrm{~S}$ (\%): C, 48.38; $\mathrm{H}, 3.25 ; \mathrm{N}, 22.57 ; \mathrm{S}$, 12.92. Found: C, 48.11; H, 3.28; N, 22.24; S, 12.84. FTIR (ATR, $\left.\mathrm{v}_{\mathrm{max}} / \mathrm{cm}^{-1}\right): 3152(\mathrm{~m}), 3124(\mathrm{~m}), 3054(\mathrm{~m}), 2952(\mathrm{~m})$, $2844(\mathrm{~m}), 2358$ (m), 2201 (vw), $1858(\mathrm{w}), 1828(\mathrm{w}), 1694$ (ms), $1612(\mathrm{w}), 1592(\mathrm{w}), 1557$ (vs), 1476 (ms), 1434 (ms), 1337 (m), 1265 (vw), 1225 (s), $1155(\mathrm{~m}), 1126$ (ms), 1084 (ms), 1008 (ms), 953 (vw), $916(\mathrm{vw}), 891$ (vw), $874(\mathrm{vw})$, $855(\mathrm{vw}), 776(\mathrm{w}), 751(\mathrm{~m}), 730(\mathrm{~m}), 641(\mathrm{w}), 623$ (vw), 557 (vw), 519 (w), 479 (w), 401 (w). ${ }^{1} \mathrm{H}$ NMR (500 MHz, DMSO- $\left.d_{6}\right) \delta: 7.35(\mathrm{~m}, 1 \mathrm{H}$, pyridine), 7,74 (s, $1 \mathrm{H}$, thiazole), 7.85 ( $\mathrm{m}, 2 \mathrm{H}$, pyridine), 8.03 (s, 1H, imine), 8.57 (dt, 1H, pyridine), 12.58 (s, $2 \mathrm{H}$, carboxylic acid and hydrazone). ${ }^{13} \mathrm{C}$ NMR (500 MHz, DMSO-d $)$ $\delta: 119.24,119.46,123.96$, 136.99, 142.21, 144.09, 149.68, 153.20, 162.46, 167.76.

Synthesis of (E)-2-(2-(quinolin-2-ylmethylene)hydrazinyl)thiazole-4-carboxylic acid (2):

Solid bromopyruvic acid $(0.07 \mathrm{~g}, 0.42 \mathrm{mmol})$ was added into the suspension of 2-quinolinecarboxaldehyde thisemicarbazone $(0.10 \mathrm{~g}, 0.43 \mathrm{mmol})$ in the mixture of water and ethanol $(20 \mathrm{~mL}, 3: 1, V /)$. The reaction mixture was stirred for $24 \mathrm{~h}$ at room temperature. The yellow product was filtered off and washed with cold water. The pure product was obtained by vapour diffusion of ethanol into DMSO solution of the crude product. Yield: $0.103 \mathrm{~g}(80 \%)$. Anal. Calcd for $\mathrm{C}_{14} \mathrm{H}_{10} \mathrm{~N}_{4} \mathrm{O}_{2} \mathrm{~S}(\%)$ : C, 56.37; H, 3.38; N, 18.78; S, 10.75. Found: C, 56.61; H, 3.55; N, 18.35; S, 11.03. FTIR (ATR, $\left.\mathrm{v}_{\mathrm{max}}{ }^{\mathrm{lm}-1}\right)$ : $3152(\mathrm{w}), 3127(\mathrm{w}), 3060(\mathrm{~m}), 2966(\mathrm{~m})$ $2920(\mathrm{~m}), 2850(\mathrm{~m}), 2519(\mathrm{w}), 1710(\mathrm{~s}), 1575$ (vs), 1503 $(\mathrm{m}), 1468(\mathrm{~m}), 1427(\mathrm{~m}), 1342(\mathrm{w}), 1307(\mathrm{~m}), 1247(\mathrm{~m})$, $1222(\mathrm{~m}), 1140(\mathrm{~s}), 1089(\mathrm{~m}), 1046(\mathrm{w}), 946(\mathrm{w}), 919(\mathrm{w})$, $876(\mathrm{vw}), 854(\mathrm{vw}), 785(\mathrm{vw}), 776(\mathrm{vw}), 742(\mathrm{~s}), 663(\mathrm{w})$, $620(w), 593(w), 543(w), 476(w), 439(v w) .{ }^{1} \mathrm{H}$ NMR (500 $\mathrm{MHz}$, DMSO- $\left.\mathrm{d}_{6}\right) \delta: 7.60(\mathrm{~m}, 1 \mathrm{H}$, quinoline), 7.76 (dd, $1 \mathrm{H}$, quinoline), $7.78(\mathrm{~s}, 1 \mathrm{H}$, thiazole), $7.97(\mathrm{~d}, 1 \mathrm{H}$, quinoline), $8.00(\mathrm{dd}, 2 \mathrm{H}$, quinoline), $8.18(\mathrm{~s}, 1 \mathrm{H}$, imine), $8.38(\mathrm{~d}, 1 \mathrm{H}$, quinoline), 12.71 (s, $2 \mathrm{H}$, carboxylic acid and hydrazone). ${ }^{13} \mathrm{C}$ NMR $\left(500 \mathrm{MHz}\right.$, DMSO-d $\left.d_{6}\right) \delta: 117.13,119.47,127.22$,
$127.81,128.17,128.92,130.26,136.85,142.24,144.14$, $147.54,153.58,162.43,167.62$.

Synthesis of $(E)-2-(2-((8-h y d r o x y q u i n o l i n-2-y l) m e t h y l-$ ene)hydrazinyl)thiazole-4-carboxylic acid (3):

Solid bromopyruvic acid $(0.07 \mathrm{~g}, 0.42 \mathrm{mmol})$ was added into the suspension of 8-hydroxyquinoline-2-carboxaldehyde thisemicarbazone $(0.10 \mathrm{~g}, 0.41 \mathrm{mmol})$ in the mixture of water and ethanol $(20 \mathrm{~mL}, 3: 1, V /)$. The reaction mixture was stirred for $24 \mathrm{~h}$ at room temperature. The yellow product was filtered off and washed with cold water. The pure product was obtained by vapour diffusion of ethanol into DMSO solution of the crude product. Yield: $0.106 \mathrm{~g}(83 \%)$. Anal. Calcd for $\mathrm{C}_{14} \mathrm{H}_{10} \mathrm{~N}_{4} \mathrm{O}_{3} \mathrm{~S}(\%)$ : C, 53.50; H, 3.21; N, 17.82; S, 10.20. Found: C, 53.17; $\mathrm{H}, 3.43$; N, 18.03; S, 10.45. FTIR (ATR, $\mathrm{v}_{\max } / \mathrm{cm}^{-1}$ ): 3391 $(\mathrm{m}), 3341(\mathrm{~m}), 3194(\mathrm{~s}), 3126(\mathrm{~m}), 2975(\mathrm{~m}), 2921(\mathrm{~m})$, $2850(\mathrm{~m}), 2701(\mathrm{w}), 2592(\mathrm{w}), 2476(\mathrm{w}), 2351(\mathrm{w}), 2319$ (w), 1691 (s), 1601 (m), 1562 (vs), 1502 (s), 1471 (s), $1429(\mathrm{~s}), 1369(\mathrm{~m}), 1347(\mathrm{vw}), 1319(\mathrm{~s}), 1270(\mathrm{w}), 1224$ (s), $1193(\mathrm{~m}), 1148(\mathrm{~s}), 1097(\mathrm{~m}), 1050(\mathrm{vw}), 1009(\mathrm{~m})$, $950(\mathrm{~m}), 878(\mathrm{vw}), 858(\mathrm{vw}), 835(\mathrm{w}), 742(\mathrm{w}), 719(\mathrm{w})$, $659(\mathrm{vw}), 620(\mathrm{vw}), 603(\mathrm{vw}), 525(\mathrm{vw}), 482(\mathrm{vw}) .{ }^{1} \mathrm{H}$ NMR $\left(500 \mathrm{MHz}, \mathrm{DMSO}-d_{6}\right) \delta: 7.60$ (m, 1H, quinoline), 7.11 (d, $1 \mathrm{H}$, quinoline), $7.38(\mathrm{~d}, 1 \mathrm{H}$, quinoline), $7.44(\mathrm{t}, 1 \mathrm{H}$, quinoline), $7.78(\mathrm{~s}, 1 \mathrm{H}$, thiazole), $7.99(\mathrm{~d}, 1 \mathrm{H}$, quinoline), $8.24(\mathrm{~s}$, $1 \mathrm{H}$, imine), 8.32 ( $\mathrm{d}, 1 \mathrm{H}$, quinoline), $9.80(\mathrm{~s}, 1 \mathrm{H}$, quinoline), $12.71\left(\mathrm{~s}, 2 \mathrm{H}\right.$, carboxylic acid and hydrazone). ${ }^{13} \mathrm{C}$ NMR $\left(500 \mathrm{MHz}, \mathrm{DMSO}-d_{6}\right) \delta:$ 112.37, 117.32, 117.98, 119.41, $128.22,128.69,136.80,138.16,142.17,144.15,151.51$, $153.45,162.45,167.67$.

Microbial strains and determination of minimal inhibitory concentration (MIC):

The antimicrobial activity was determined using five strains of the Gram-positive bacteria Staphylococcus aureus (ATCC 6538), Micrococcus luteus (ATCC 4698), Micrococcus luteus (ATCC 10240), Clostridium sporogenes (ATCC 19404), Bacillus subtilis (ATCC 6633), five different strains of the Gram-negative bacteria: Escherichia coli (ATCC 25922), Salmonella enterica subsp. enterica serovar Enteritidis (ATCC 13076), Proteus hauseri (ATCC 13315), Pseudomonas aeruginosa (ATCC 9027), Klebsiella pneumoniae (ATCC 10031), and three strains of the fungi: Candida albicans (ATCC 10231), Sacharomyces cerevisiae (ATCC 9763) and Aspergillus brasiliensis (ATCC 16404). For the experiments, bacteria were cultivated in Mueller-Hinton (MH) agar and broth (Biolab, Hungary), while Sabouraud dextrose agar and broth (Torlak, Belgrade, Serbia) were used for fungi. Broth microdilution method [10] was used to determine the MIC of the investigated compounds. Briefly, test compounds were initially dissolved in DMSO (stock solution concentrations were $10 \mathrm{mg} / \mathrm{mL}$ ). The microplates were filled with 100 $\mu \mathrm{L}$ of Mueller-Hinton broth for bacteria and Sabouraud dextrose broth for yeasts and fungi, then $100 \mu \mathrm{L}$ of an aliquot from the stock solution of the tested compounds was added into the first row of the plate and double diluted 
by using a multichannel pipette. Bacterial and fungal cultures were suspended in sterile $0.9 \%$ saline, and turbidity was adjusted to $0.5 \mathrm{McF}$ arland. A $10 \mu \mathrm{L}$ of diluted bacterial or spore suspension was added to each well to give a final concentration of $5 \times 10^{5}$ colony forming units per $\mathrm{mL}(\mathrm{CFU} / \mathrm{mL})$ for bacteria and $5 \times 10^{3} \mathrm{CFU} / \mathrm{mL}$ for fungi. Experiments were done in triplicate. Microtiter plates were incubated at $37^{\circ} \mathrm{C}$ without shaking for $18 \mathrm{~h}$. Erythromycin was used as a positive control for bacteria, amphotericin $B$ was used as a positive control for fungi, while water and DMSO served as negative controls. Lastly, $10 \mu \mathrm{L}$ of oxidation-reduction indicator resazurin $(0.6 \%)$ was added to each well to evaluate cell growth. The lowest concentration, which showed no change in color, was defined as the MIC.

Assessment of antioxidant capacity:

ABTS scavenging antioxidant assay: Stock solution of $\mathrm{ABTS}^{++}$was obtained by reacting $0.5 \mathrm{~mL}$ of $14 \mathrm{mM} \mathrm{ABTS}$ (3.6 $\mathrm{mg}$ ) and $0.1 \mathrm{~mL}$ of $5 \mathrm{mM}$ potassium persulfate $(1.32 \mathrm{mg}$ in $1 \mathrm{~mL}$ of water). Before use, this solution was diluted with methanol to the absorbance of 1.600 at $734 \mathrm{~nm} .1 .5$ $\mathrm{mL}$ of $\mathrm{ABTS}^{++}$reagent was added to $0.5 \mathrm{~mL}$ of the assay substances of different appropriate concentrations. The control contained methanol instead of substance solutions or standard antioxidants. The reaction mixtures were incubated for $30 \mathrm{~min}$ at room temperature; their absorbances were then measured at $734 \mathrm{~nm}$ versus methanol as a blank. The decrease in the absorbance of the samples at $734 \mathrm{~nm}$ compared to the control sample $(100 \%)$ is proportional to samples' antioxidant activity [11]. Scavenging activity was calculated according to eq. (1).

Scavenging activity $(\%)=100 \times($ Acontrol - Asample $) /$ Acontrol.

DPPH scavenging antioxidant assay: The proton donating ability was assayed using a protocol to determine radical scavenging activity [12]. The compounds were dissolved in DMSO and were diluted into ten different concentrations (the range of concentration was $3330-6.5 \mu \mathrm{g} / \mathrm{mL}$ ). Commercially available DPPH was dissolved in methanol at a concentration of $6.58 \times 10^{-5} \mathrm{M} .140 \mu \mathrm{L}$ of DPPH solution and $10 \mu \mathrm{L}$ of DMSO solution of test compounds were added to a 96-well microplate, while the control was pure DMSO $(10 \mu \mathrm{L})$.

The microplate was incubated for $30 \mathrm{~min}$ at $25^{\circ} \mathrm{C}$ in the dark, and the absorbance was measured at $517 \mathrm{~nm}$. The scavenging activity of the compounds was calculated using the eq. (1). $I C_{50}$ is defined as the concentration of antioxidant agent necessary to reduce the starting amount of DPPH by $50 \%$, and is calculated from the concentration-dependent free radical scavenging activity graph. Ascorbic acid was used as a control.

Total antioxidant capacity (TAOC) (modified phosphomolybdenum method): Volume of $0.4 \mathrm{~mL}$ of sample solutions $(50-1000 \mu \mathrm{M})$ was mixed with $1.6 \mathrm{~mL}$ of reagent solution ( $0.6 \mathrm{M}$ sulfuric acid, $28 \mathrm{mM}$ sodium phosphate, and
$4 \mathrm{mM}$ ammonium molybdate) and resulting mixtures were incubated at $95^{\circ} \mathrm{C}$ for $90 \mathrm{~min}$. The cooled reaction mixtures were then centrifuged (3000 rpm for $10 \mathrm{~min}$ ). The absorbance of the supernatant solution was measured 1 $\mathrm{h}$ after centrifugation, at $695 \mathrm{~nm}$, against the reagent solution as blank. An increased absorbance in reading in the assays indicated increased antioxidant power, expressed as $\mathrm{EC}_{50}$ values (the sample concentration giving absorbance of 0.500 from the graph of absorbance at $695 \mathrm{~nm}$ against compound concentration) [13].

Nitrogen(II)-oxide radical ('NO) antioxidant scavenging assay:

The determination of the ability of a substance to neutralize ${ }^{\circ} \mathrm{NO}$ is based on spectrophotometric measurement of the concentration of formed nitrite ions $\left(\mathrm{NO}_{2}^{-}\right)$. Aqueous sodium nitroprusside solution is a source of ${ }^{2} \mathrm{NO}$ radicals at physiological $\mathrm{pH}$. Formed radicals react with oxygen to give nitrite ions whose concentration is determined spectrophotometrically based on the Griess-Ilosvori reaction. The principle for determining the concentration of nitrite ions is based on monitoring the formation of the violetpink diazo complex, the reaction product of $\mathrm{NO}_{2}^{-}$and Griess reagents at room temperature, which has a maximum absorption at $540 \mathrm{~nm}$ [14]. Reaction mixtures of the following composition were made in wells of a microtiter plate: $10 \mu \mathrm{L}$ of tested substance or the standard, $60 \mu \mathrm{L}$ of sodium nitroprusside $(5 \mathrm{mM})$ and $50 \mu \mathrm{L}$ of buffer $(0.1 \mathrm{M}$ phosphate buffer $\mathrm{pH}$ 7.0). The samples were then incubated for $100 \mathrm{~min}$ in the light at room temperature. Afterwards, $120 \mu \mathrm{L}$ of Gries reagent $(0.77 \mathrm{mM} \mathrm{N}$-(1-naphthyl)ethylenediamine dichloride with $1 \%$ sulfanilamide in $5 \%$ phosphoric acid) was added, and the resulting mixtures were carefully mixed. After $15 \mathrm{~min}$, the absorbances of the obtained chromophores at $540 \mathrm{~nm}$ were measured on an ELISA reader.

Oxygen radical absorbance capacity (ORAC) assay:

The assay was performed by modified original protocol [15]. Stock solutions of fluorescein substrate $(5 \mu \mathrm{M})$ and free radical generator AAPH $(0.5 \mathrm{M})$ were prepared in 75 $\mathrm{mM}$ potassium phosphate buffer ( $\mathrm{pH}$ 7.4). The volume of $100 \mu \mathrm{L}$ of sample solutions or Trolox in DMSO $(20 \mu \mathrm{M})$ were mixed with $1485 \mu \mathrm{L}$ of buffer and $15 \mu \mathrm{L}$ of fluorescein solution. The $30 \mathrm{~min}$ reaction at $37^{\circ} \mathrm{C}$ was initiated by adding $250 \mu \mathrm{L}$ of AAPH solution. Fluorescence conditions were as follows: excitation and emission wavelengths 485 and $511 \mathrm{~nm}$, respectively, slits $2 \mathrm{~nm}$. The relative sample ORAC value was expressed as Trolox equivalents (TE).

Hydroxyl radical absorbance capacity (HORAC) assay: The HORAC assay measures the hydroxyl radical scavenging capacity of tested substances. It was performed by the literature protocol [16]. Cobalt(II) fluoride is an oxidant that generates hydroxyl radicals in a Fentonlike reaction involving hydrogen peroxide. Fluorescein is a fluorescent probe that begins to decay in the presence of hydroxyl radicals, resulting in a loss of fluorescence 
over time. A volume of $1.485 \mathrm{~mL}$ of phosphate buffer (75 $\mathrm{mM}, \mathrm{pH} 7.4), 15 \mu \mathrm{L}$ of fluorescein solution $(5 \mu \mathrm{M})$, and $0.25 \mathrm{~mL}$ of test sample were pipetted into a spectrofluorimetry cuvette $(3 \mathrm{~mL})$. The control solution contained an identical buffer volume instead of a sample. The prepared mixture was carefully stirred and incubated for $5 \mathrm{~min}$ at room temperature. A volume of $0.1 \mathrm{~mL}$ of $\mathrm{H}_{2} \mathrm{O}_{2}(1.1 \mathrm{M})$ and $0.1 \mathrm{~mL}$ of cobalt(II) solution (prepared by dissolving $15.7 \mathrm{mg}$ of cobalt(II) fluoride tetrahydrate and $20 \mathrm{mg}$ of picolinic acid in $10 \mathrm{~mL}$ of milliQ water) were added to the cuvette, and fluorescence measurement was started immediately. Fluorescence was measured every $60 \mathrm{~s}$ for $30 \mathrm{~min}$ at $37^{\circ} \mathrm{C}$. The excitation wavelength was set to $485 \mathrm{~nm}$ and the emission wavelength to $511 \mathrm{~nm}$, with a slit width of $2 \mathrm{~nm}$ for both the excitation and emission monochromator. Based on the integration of the areas under the obtained curves, the antioxidant activity (AOA) of the substance is estimated, expressed in terms of Trolox ${ }^{\circledR}$ equivalents: $\mathrm{AOA}=\left(\mathrm{AUC}_{\text {Trolox }}-\mathrm{AUC}_{\text {blank }}\right) /\left(\mathrm{AUC}_{\text {Trolox }}-\mathrm{AUC}_{\text {blank }}\right) \times\left(\mathrm{C}_{\text {Trolox }}\right.$ / $C_{\text {sample }}$ ), where AUC is the area under the curve and $C$ is the concentration of substances in $\mathrm{mol} / \mathrm{L}$.

Prediction of ADMET parameters and pan-assay interference compounds (PAINS) evaluation:

Physicochemical properties, lipophilicity, water-solubility, pharmacokinetics, drug-likeness, and medicinal chemistry parameters were determined using the free SwissADME tools available at the website of the Swiss Institute of Bioinformatics (http://www.swissadme.ch/) [17]. The structures were constructed and converted into SMILES format.

\section{Results and discussion}

Compounds 1-3 were prepared using the Hantzsch reaction between bromopyruvic acid and thiosemicarbazones of the corresponding carbonyl compounds. The addition of water in ethanol solutions enables deprotonation of hydrobromide salts, which may form in the pure ethanol, and precipitation of neutral ligands in the form of yellow solids [18]. The composition of the compounds determined by elemental analysis, is consistent with the formulas depicted in Figure 3.

In the FTIR spectra of compounds 1-3 at the highest frequencies region $\left(3391-3054 \mathrm{~cm}^{-1}\right)$, bands from $\mathrm{v}(\mathrm{O}-\mathrm{H})$ and $\mathrm{N}-\mathrm{H}$ stretching vibrations were observed. The strong bands in the region $1710-1690 \mathrm{~cm}^{-1}$, characteristic for stretching vibration of $\mathrm{C}=\mathrm{O}$ bond, were identified in FTIR spectra of all compounds. Very strong bands, originating from $\mathrm{C}=\mathrm{N}$ stretching vibrations, were observed in the region 1574-1556 $\mathrm{cm}^{-1}$. The bands from stretching vibrations of $\mathrm{C}-\mathrm{S}$ bonds from thiazole ring were identified in the spectral region $855-828 \mathrm{~cm}^{-1}$. In the absorption region between $751 \mathrm{~cm}^{-1}$ and $401 \mathrm{~cm}^{-1}$, bands originating from the ring vibrations were observed.

The compounds 1-3 can exist in two isomeric forms, as $E$ and $Z$ isomers. The characteristic of $Z$ isomers is the existence of an intramolecular hydrogen bond between
$\mathrm{N}-\mathrm{NH}$ hydrogen atom and the pyridine/quinoline nitrogen atom. Since the signals of an imine hydrogen atom in ${ }^{1} \mathrm{H}$ NMR spectra of the compounds are in the narrow region 12.58-12.71 ppm and intramolecular hydrogen bond in Z-isomeric forms cause significant downfield shift ( 2-3 ppm) of $\mathrm{N}-\mathrm{NH}$ hydrogen atom signal $[19,20]$, it can be assumed that 1-3 are present in the DMSO- $d_{6}$ solution in their $E$-isomeric forms. All the other signals in ${ }^{1} \mathrm{H}$ and ${ }^{13} \mathrm{C}$ NMR spectra are in the range previously observed for the related compounds [18,21].
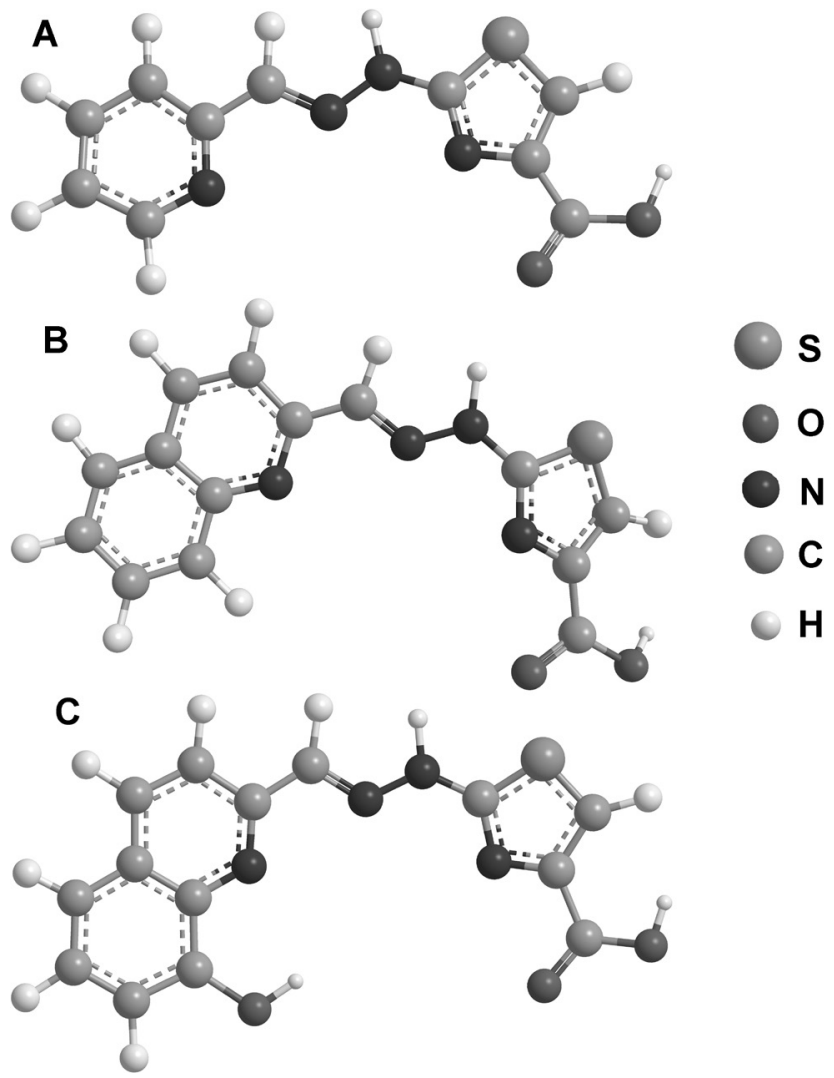

Figure 3 Structures of $1-3$. Spatial orientation of pyridine/quinoline moieties and thiazole ring in the molecules of $1-3$, obtained by energy minimization using the MM2 force field in the ChemBio3D Ultra 13.0 software package

Antimicrobial activity of 1-3 was evaluated by broth dilution method and expressed as MIC values. Antibacterial activity was tested on five Gram-negative bacterial strains (E. coli, P. aeruginosa, P. hauseri, K. pneumoniae and $S$. enterica), as well as four Gram-positive bacteria ( $S$. aureus, M. luteus ATCC 4698 and 10240, B. subtilis and C. sporogenes). The results of the antibacterial activity of the tested compounds are given in Table 1.

Generally, quinoline-based compounds $\mathbf{2}$ and $\mathbf{3}$ are more active on all Gram-negative bacteria and fungi. In the case of Gram-negative bacteria, an additional hydroxyl group resulted in better activity. In the case of Gram-positive bacteria, 2 showed the most potent activity except for M. Iuteus ATCC 10240 where 1 was the most active compound.

The antifungal activity of the investigated compounds was examined against $S$. cerevisiae, A. brasiliensis and $C$. albicans (Table 2). 
Table 1. Antimicrobial activity of 1-3 expressed as MIC values (in mM)

\begin{tabular}{|c|c|c|c|c|c|c|c|c|c|c|}
\hline & E.coli & $\begin{array}{l}P . \\
\text { aeruginosa }\end{array}$ & $\begin{array}{l}P . \\
\text { hauseri }\end{array}$ & $\begin{array}{l}\text { K. } \\
\text { pneumoniae }\end{array}$ & $\begin{array}{l}\text { S. } \\
\text { enterica }\end{array}$ & $\begin{array}{l}S . \\
\text { aureus }\end{array}$ & $\begin{array}{l}\text { M. } \\
\text { luteus }\end{array}$ & $\begin{array}{l}\text { M. } \\
\text { luteus }\end{array}$ & $\begin{array}{l}\text { B. } \\
\text { subtilis }\end{array}$ & $\begin{array}{l}\text { C. } \\
\text { sporogenes }\end{array}$ \\
\hline & & & & & & & $\begin{array}{l}\text { ATCC } \\
4698\end{array}$ & $\begin{array}{l}\text { ATCC } \\
10240\end{array}$ & & \\
\hline 1 & 5.035 & 5.035 & 5.035 & 5.035 & 5.035 & 5.035 & 5.035 & 5.035 & 5.035 & 5.035 \\
\hline 2 & 2.095 & 4.190 & 2.095 & 4.190 & 2.095 & 4.190 & 1.048 & 8.380 & 4.190 & 4.190 \\
\hline 3 & 1.988 & 3.977 & 3.977 & 3.977 & 3.977 & 7.954 & 7.954 & 7.954 & 7.954 & 3.977 \\
\hline Erythromycin & 0.038 & 0.076 & 0.038 & 0.038 & 0.038 & 0.076 & 0.019 & 0.038 & 0.076 & 0.076 \\
\hline
\end{tabular}

Table 2. Antifungal activity of 1-3 expressed as MIC values (in $\mathrm{mM}$ )

\begin{tabular}{cccc}
\hline & C. albicans & A. brasiliensis & S. cerevisiae \\
\hline $\mathbf{1}$ & 10.070 & 5.035 & 5.035 \\
$\mathbf{2}$ & 2.095 & 4.190 & 4.190 \\
$\mathbf{3}$ & 3.977 & 1.988 & 3.977 \\
Amphotericin B & 0.022 & 0.044 & 0.011 \\
\hline
\end{tabular}

As previously noted for bacterial strains, the quinolinebased compounds were generally more active, and the addition of hydroxyl group resulted in the better activity of compound 3 against $A$. brasiliensis and $S$. cerevisiae.

Oxidative stress is a normal physiological phenomenon in healthy individuals associated with aging processes. It is also considered as the primary contributor to many pathological conditions: diabetes, malignancy, pulmonary and autoimmune diseases, inflammation, neurodegenerative diseases, viral infections, and more [22]. Compounds that can slow down the oxidation processes in the human body are known as antioxidants. They act as "scavengers" of various free radicals or electron donors and thus prevent chain reactions in which cells are damaged. In addition to natural antioxidants such as flavonoids, synthetic antioxidants have been developed and used in practice as additives, supplements, and drugs.

Various antioxidative assays were developed for testing of antioxidative capacity. The widely used ABTS assay is based on formation of ABTS anion radicals. The green-blue ABTS solution is decolorized in the presence of antioxidant scavengers, which can be monitored spectrophotometrically by measuring the absorbance at $734 \mathrm{~nm}$. In the DPPH assay, the color change of a purple-colored solution of a stable DPPH radical to a yellow-colored reduced form is monitored. In the TAOC assay, an antioxidant reduces $\mathrm{Mo}(\mathrm{VI})$ to $\mathrm{Mo}(\mathrm{V})$, with the formation of the blue-green phosphate $\mathrm{Mo}(\mathrm{V})$ complex at acidic $\mathrm{pH}$ [13]. The capacity of scavenging ${ }^{\circ} \mathrm{NO}$ free radical is monitored indirectly by measuring concentration of nitrite ions formed in the reaction between $\mathrm{NO}$ and $\mathrm{O}_{2}$ [23]. The HORAC assay is based on scavenging of hydroxyl radicals, which are produced by hydroxyl radical initiator $\left(\mathrm{H}_{2} \mathrm{O}_{2}\right)$ and Fenton reagent, while an antioxidant compound in the ORAC assay scavenges peroxyl radicals, which are generated using $A A P H$. Free radical scavenging activity in the HORAC and ORAC assays is monitored by decreasing in fluorescence of fluorescein over time [24]. In the ABTS, DPPH, and 'NO antioxidative assays, results are expressed in the form of $\mathrm{IC}_{50}$ value, which is the sample concentration that results in a $50 \%$ inhibition activity (free radical scavenging). The relative ORAC and HORAC value for the samples were expressed as Trolox equivalents (TE). In the TAOC assay, the activity is expressed as $\mathrm{EC}_{50}$ value - a sample concentration that gives absorbance of 0.5 . In the mentioned assays, Trolox (a water-soluble vitamin E analog) and ascorbic acid (vitamin C) served as positive controls.

In our previous work, we tested the antioxidative capacity of three pyridine-based THs $\left(\mathrm{HLS}^{1-3}\right)$ in all six mentioned antioxidative assays $[6,18]$. $\mathrm{HLS}^{1-3}$ differ from 1 since they possess phenyl, methylphenyl, and methoxyphenyl groups instead of the carboxyl group. All three compounds showed appreciable activities in ABTS, DPPH, and ${ }^{\circ} \mathrm{NO}$ assays. In the DPPH assay, HLS ${ }^{1}$ showed the same level of activity as vitamin $\mathrm{C}$, while $\mathrm{HLS}^{2}$ was identified as more active compound in the ABTS assay compared with the standards. All three compounds were more active in ${ }^{\circ} \mathrm{NO}$ assay than both standards $[6,18]$.

The results of the antioxidative capacity of 1-3 in six antioxidative assays are presented in Table 3.

The obtained data indicate a significant influence of the replacement of various aromatic groups in $\mathrm{HLS}^{1-3}$ with the carboxylic group in 1. In the case of ABTS, TAOC, ORAC, and HORAC assays, such replacement has a negative effect on antioxidative capacity. In the case of DPPH assay, the opposite trend was observed since 1 was identified as the most active compound, twice as active as vitamin $C$. The positive effect of replacing the pyridine ring in 1 with the quinoline ring in $\mathbf{2}$, was observed in all assays, excluding the DPPH assay. The Introduction of the hydroxyl group in quinoline ring in $\mathbf{3}$ has a positive effect in ABTS and DPPH assays, negligible effect in ${ }^{\circ} \mathrm{NO}$ assay, and negative effect in HORAC assay. In sum, 3 appeared to be more active than both standards (Trolox and vitamin C) in ABTS assays, while both 1 and 3 were more active than the standards in the DPPH assay. In ${ }^{\bullet} \mathrm{NO}$ assay, all three compounds were more active than vitamin $\mathrm{C}$. In contrast, in the case of ORAC assay, both quinoline-based compounds showed activity comparable to the activity of vitamin $\mathrm{C}$. Similar was noticed in the case of the HORAC assay, but only for compound . 
Table 3. Antioxidant capacity of 1-3a

\begin{tabular}{|c|c|c|c|c|c|c|}
\hline & $\begin{array}{c}\text { ABTS } \\
\mathrm{IC}_{50}(\mathrm{mM})\end{array}$ & $\begin{array}{c}\text { DPPH } \\
I_{50} \\
(\mathrm{mM})\end{array}$ & $\begin{array}{c}\text { TAOC } \\
\mathrm{EC}_{50}(\mathrm{mM})\end{array}$ & $\begin{array}{l}\bullet \mathrm{NO} \\
\mathrm{IC}_{50} \\
(\mathrm{mM})\end{array}$ & $\begin{array}{l}\text { ORAC } \\
(T E)\end{array}$ & $\begin{array}{c}\text { HORAC } \\
\text { (TE) }\end{array}$ \\
\hline 1 & $0.323 \pm 0.003$ & $\begin{array}{c}0.036 \pm \\
0.006\end{array}$ & $>1.5$ & $0.656 \pm 0.020$ & $0.304 \pm 0.001$ & $0.157 \pm 0.011$ \\
\hline 2 & $0.144 \pm 0.006$ & $\begin{array}{c}0.085 \pm \\
0.008\end{array}$ & $\begin{array}{c}0.831 \pm \\
0.020\end{array}$ & $0.336 \pm 0.015$ & $0.842 \pm 0.015$ & $0.882 \pm 0.009$ \\
\hline 3 & $0.110 \pm 0.003$ & $\begin{array}{c}0.046 \pm \\
0.007\end{array}$ & $\begin{array}{c}0.846 \pm \\
0.018\end{array}$ & $0.358 \pm 0.017$ & $0.845 \pm 0.013$ & $0.597 \pm 0.007$ \\
\hline Trolox & $0.138 \pm 0.004$ & $\begin{array}{c}0.202 \pm \\
0.005\end{array}$ & $\begin{array}{c}0.151 \pm \\
0.003\end{array}$ & $>1.5 \pm 0.03$ & 1 & 1 \\
\hline vitamin C & $0.232 \pm 0.005$ & $\begin{array}{c}0.079 \pm \\
0.006\end{array}$ & $\begin{array}{c}0.240 \pm \\
0.004\end{array}$ & $0.710 \pm 0.023$ & $0.885 \pm 0.033$ & $0.912 \pm 0.022$ \\
\hline
\end{tabular}

Table 4. Pharmacological profiles, medicinal chemistry principles and lead-likeness properties of compounds $1-3$

\begin{tabular}{|c|c|c|c|}
\hline Compound & 1 & 2 & 3 \\
\hline \multicolumn{4}{|l|}{ Physicochemical properties } \\
\hline Molecular weight (Mw & 248.26 & 298.32 & 314.32 \\
\hline \#Heavy atoms & 17 & 21 & 22 \\
\hline \#Aromatic heavy atoms & 11 & 15 & 15 \\
\hline Fraction $\mathrm{Csp}^{3}$ & 0 & 0 & 0 \\
\hline \#Rotatable bonds & 4 & 4 & 4 \\
\hline \#H-bond acceptors & 5 & 5 & 6 \\
\hline \#H-bond donors & 2 & 2 & 3 \\
\hline Molar Refractivity & 64.35 & 81.85 & 83.88 \\
\hline $\begin{array}{l}\text { Topological Polar Surface Area } \\
\left(\text { TPSA; } \AA^{2}\right)\end{array}$ & 115.71 & 115.71 & 135.94 \\
\hline $\log P_{o / w}$ & 1.25 & 2.27 & 1.93 \\
\hline \multicolumn{4}{|l|}{ Pharmacokinetics } \\
\hline Gl absorption & $++^{a}$ & ++ & ++ \\
\hline BBB permeant & $-\mathrm{b}$ & - & - \\
\hline Pgp substrate & - & - & - \\
\hline CYP1A2 inhibitor & - & $+c$ & - \\
\hline CYP2C19 inhibitor & - & - & - \\
\hline CYP2C9 inhibitor & - & - & - \\
\hline CYP2D6 inhibitor & - & - & - \\
\hline CYP3A4 inhibitor & - & - & - \\
\hline $\log \mathrm{Kp}(\mathrm{cm} / \mathrm{s})$ & -6.37 & -5.73 & -6.08 \\
\hline \multicolumn{4}{|l|}{ Druglikeness } \\
\hline Lipinski \#violations & 0 & 0 & 0 \\
\hline Ghose \#violations & 0 & 0 & 0 \\
\hline Veber \#violations & 0 & 0 & 0 \\
\hline Egan \#violations & 0 & 0 & 1 (TPSA>131.6) \\
\hline Muegge \#violations & 0 & 0 & 0 \\
\hline Bioavailability score & 0.56 & 0.56 & 0.56 \\
\hline \multicolumn{4}{|l|}{ Medicinal Chemistry } \\
\hline PAINS \#alerts & 0 & 0 & 0 \\
\hline \multirow[t]{3}{*}{ Leadlikeness } & No & Yes & Yes \\
\hline & (1 violation: & & \\
\hline & $\mathrm{MW}<250$ ) & & \\
\hline Synthetic accessibility & 2.92 & 3.02 & 3.01 \\
\hline
\end{tabular}


One of the main reasons for the frequent failure to develop drug-like candidates is the risk of unwanted adverse side effects and poor bioavailability in in vivo assays. To reduce the time and cost of analysis of molecules without desirable pharmacokinetic or pharmacodynamic profiles, many in-silico platforms for evaluation of several physicochemical, pharmacokinetics, and medicinal chemistry properties have been developed [25]. The in-silico ADMET profiles of 1-3 were assessed through a robust SwissADME program, and the results are presented in Table 4.

All compounds showed desirable Lipinski rule principles like molecular weight $\leq 500, \mathrm{H}$-bond acceptors $\leq 10$, $\mathrm{H}$-bond donors $\leq 5$, and 1-octanol / water partition coefficient $\left(\log \mathrm{P}_{\mathrm{o} / \mathrm{w}} \leq 5\right)$ values [26]. Other physicochemical properties, such as a number of rotatable bonds $(\leq 10)$, molar refractivity (from 40 to 130), and topological polar surface area (TPSA $\leq 140 \AA^{2}$ ), were also found within the acceptable range. All compounds are predicted to be highly absorbed by the gastrointestinal (GI) system after oral administration, but only 2 can be metabolized through cytochrome P450 gene $1 \mathrm{~A}^{2}$ isoform. Relevant strategies for selecting molecules with preferred druglike profiles examined by SwissADME indicate that the most active compounds 2 and 3 represent drug candidates since they possess critical functional groups and bioavailability. Finally, according to the recently published editorial by Aldrich et al. [27], to exclude artificial activity, in addition to SwissADME, the compounds have been evaluated by ZINC PAINS Pattern Identifier [28]. The applied algorithms did not report our compounds as potential PAINS or covalent inhibitors.

Physico-chemical space for oral bioavailability of the compunds is shown in Figure 4. The grey-coloured zone represents the suitable physico-chemical space. In an ideal case, six properties should be in the desirable range (lipophility: $-0.7<\log \mathrm{P}_{\mathrm{o} / \mathrm{w}}<+5$; size: $150 \mathrm{~g} / \mathrm{mol}<$ Mw < $500 \mathrm{~g} / \mathrm{mol}$; polarity: $20 \AA^{2}<$ TPSA $<130 \AA^{2}$; insolubility: $0<\log S<6$; insaturation: $0.25<$ fraction $\mathrm{Csp}^{3}<1$; flexibility: $0<$ \# Rotatable bonds < 9). All the compounds show desirable values of lipophility, size, insolubility and flexibility. Compounds 1 and $\mathbf{2}$ have polarity in the desirable range, while 3 as the most polar falls outside of the desirable range. Since the compounds do not contain $\mathrm{sp}^{3}$ hybridized carbon atoms, they do not possess the suitable fraction of $\mathrm{Csp}^{3}$.

Considering all calculated parameters and results of antimicrobial activity and antioxidative capacity, compound 2 may represent the excellent candidate for the lead compound.

\section{Conclusion}

In this work, three novel N-heteroaromatic THs (1-3) are reported. Their composition was determined by elemental analysis, while the characterization was done by IR and NMR spectroscopy. Antimicrobial activity study indicated that quinoline-based compounds are more ac- tive against Gram-negative bacteria and fungi tested than pyridine-based compounds. It is important to emphasize that 2 showed eight-times better activity against $M$. Iuteus ATCC 4698 compared to M. luteus ATCC 10240. Studies of antioxidative capacity revealed that quinolinebased compounds have more potent activities in five out of the six assays performed (ABTS, TAOC, NO, ORAC and HORAC) than their pyridine analogs HLS1-3 and 1. Compound 2 showed the best pharmacological profile, medicinal chemistry principles, and lead-likeness properties among the tested compounds. Taking into account the results of antimicrobial activity and antioxidative capacity, compound 2 represents a good lead drug candidate. The results obtained in this study may contribute to the further design of novel THs with more potent antimicrobial and antioxidant activities.

\section{Acknowledgments}

The authors acknowledge the financial support of the Ministry of Education, Science and Technological Development of the Republic of Serbia (Contract No's. 45103-9/2021-14/200288, 451-03-68/2020-14/200168 and 451-03-9/2021-14/200026).

\section{Abbreviations and symbols}

FDA - The Food and Drug Administration (agency)

THs - (Thiazolyl-2-yl)hydrazones

FTIR - Fourier transform infrared spectroscopy

NMR - Nuclear magnetic resonance spectroscopy

ADMET - Absorption, distribution, metabolism, excretion, and toxicity (parameters)

ABTS - Azino-bis(3-ethylbenzothiazoline-6-sulfonic acid) diammonium salt

DPPH - Diphenyl-1-picrylhydrazyl

AAPH - 2,2'-Azobis(2-methylpropionamidine) dihydrochloride

Trolox - ( \pm )-6-Hydroxy-2,5,7,8-tetramethylchromane2-carboxylic acid

ATR - Attenuated Total Reflection

MIC - Minimal inhibitory concentration

TAOC - Total antioxidant capacity

ORAC - Oxygen radical absorbance capacity HORAC - Hydroxyl radical absorbance capacity

PAINS - Pan-assay interference compounds

TPSA - topological polar surface area

\section{References}

[1] J. Y.W. Mak, W. Xu, D. P. Fairlie, Peptidomimetics I, Topics in Heterocyclic Chemistry, Springer Berlin Heidelberg, 2015., p. 235-266.

[2] S. Forli, Epothilones: from discovery to clinical trials, Current Topics in Medicinal Chemistry, 14(20) (2014) 2312-2321.

[3] W. Hastings, Chemistries and colors of bioluminescent reactions: a review, Gene, 173(1) (1996) 5-11.

[4] A. Petrou, M. Fesatidou, A. Geronikaki, Thiazole Ring - A Biologically Active Scaffold, Molecules, 26(11) (2021) 3166. 
[5] https://go.drugbank.com/

[6] J. B. Araškov, M. Nikolić, S. Armaković, S. Armaković, Marko Rodić, A. Višnjevac, J. M. Padrón, T. R. Todorović, N. R. Filipović, Structural, antioxidant, antiproliferative and in-silico study of pyridine-based hydrazonyl-selenazoles and their sulphur isosteres, Journal of Molecular Structure, 1240 (2021) 130512.

[7] S. Chandraa, S. Raizada, M. Tyagi, P. K. Sharma, Spectroscopic and biological approach of $\mathrm{Ni}(\mathrm{II})$ and $\mathrm{Cu}(\mathrm{II})$ complexes of 2-pyridinecarboxaldehyde thiosemicarbazone, Spectrochimica Acta Part A: Molecular and Biomolecular Spectroscopy, 69(3) (2008) 816-821.

[8] F. Bisceglie, A. Musiari, S. Pinelli, R. Alinovi, I. Menozzi, E. Polverini, P. Tarasconi, M. Tavone , G. Pelosi, Quinoline-2carboxaldehyde thiosemicarbazones and their $\mathrm{Cu}(\mathrm{II})$ and $\mathrm{Ni}$ (II) complexes as topoisomerase Ila inhibitors, Journal of Inorganic Biochemistry, 152 (2015) 10-19.

[9] D. Rogolinoa, A. Cavazzoni, A. Gatti, M. Tegoni, G.Pelosi, V. Verdolino, C. Fumarola, D. Cretella, P. G. Petronini, M. Carcelli, Anti-proliferative effects of copper(II) complexes with hydroxyquinoline-thiosemicarbazone ligands, European Journal of Medicinal Chemistry, 128 (2017) 140-153.

[10] European Committee for Antimicrobial Susceptibility Testing (EUCAST) of the European Society of Clinical Microbiology and Infectious Diseases (ESCMID), Determination of minimum inhibitory concentrations (MICs) of antibacterial agents by broth dilution, Clinical Microbiology and Infection 9 (8) (2003) IX-XV.

[11] A. A. Bollgon, M. M. Machado, M. L. Athayde, Technical Evaluation of Antioxidant Activity, Medicinal Chemistry, 4 (2014) 517-522.

[12] R. L. Prior, X. Wu, K. Schaich, Standarized Methods for the Determination of Antioxidant Capacity and Phenolics in Foods and Dietary Supplements, Journal of Agricultural Food Chemistry, 53 (2005) 4290-4302.

[13] P. Prieto, M. Pineda, M. Aguilar, Spectrophotometric Quantitation of Antioxidant Capacity through the Formation of a Phosphomolybdenum Complex: Specific Application to the Determination of Vitamin E, Analytical Biochemistry, 269 (1999) 337-341.

[14] J. B. Habu, B. O. Ibeh., In vitro antioxidant capacity and free radical scavenging evaluation of active metabolite constituents of Newbouldia laevis ethanolic leaf extract, Biological Research, 48(1) (2015) 16.

[15] B. Ou, M. Hampsch-Woodill, R.L. Prior, Development and Validation of an Improved Oxygen Radical Absorbance Capacity Assay Using Fluorescein as the Fluorescent Probe, Journal of Agricultural and Food Chemistry, 49 (2001) 4619-4626.

[16] B. Ou, M. Hampsch-Woodill, J. Flanagan, E. K. Deemer, R. L. Prior, D. Huang, Novel fluorometric assay for hydroxyl radical prevention capacity using fluorescein as the probe Journal of Agricultural and Food Chemistry, 50 (2002) 2772-2777.

[17] A. Daina, O. Michielin, V. Zoete, SwissADME: a free web tool to evaluate pharmacokinetics, drug-likeness and medicinal chemistry friendliness of small molecules, Scientific Reports, 7 (2017) 42717.

[18] N. R. Filipović, H. Elshaflu, S. Grubišić, Lj. S. Jovanović, M. Rodić, I. Novaković, A. Malešević, I. S. Djordjević, H. Li, N. Šojić, A. Marinković, T. R. Todorović, Co(III) complexes of (1,3-selenazol-2-yl)hydrazones and their sulphur analogues, Dalton Transactions, 46 (2017) 29102924.

[19] N. Filipović, T. Todorović, R. Marković, A. Marinković, S. Tufegdžić, D. Godjevac, K. Andjelković, Synthesis, characterization and biological activities of $\mathrm{N}$-heteroaromatic hydrazones and their complexes with $\mathrm{Pd}(\mathrm{II}), \mathrm{Pt}(\mathrm{II})$ and $\mathrm{Cd}(\mathrm{II})$, Transition Metal Chemistry, 35 (2010) 765-772.

[20] C. R. Kowol, W. Miklos, S. Pfaff, S. Hager, S. Kallus, K. Pelivan, M. Kubanik, É. A. Enyedy, W. Berger, P. Heffeter and B. K. Keppler, Impact of Stepwise NH2-Methylation of Triapine on the Physicochemical Properties, Anticancer Activity, and Resistance Circumvention, Journal of Medicinal Chemistry, 59 (2016) 6739-6752.

[21] H. Elshaflu, S. Bjelogrlić, C. D. Muller, T. R. Todorović, M. Rodić, A. Marinković, N. R. Filipović, Co(III) complex with (E)-2-(2-(pyridine-2-ylmethylene)hydrazinyl)- 4-(4-tolyl)1,3-thiazole: structure and activity against 2-D and 3-D cancer cell models, Journal of Coordination Chemistry, 69(22) (2016), 3354-3366.

[22] S. Kalam, M. Z. Gul, R. Singh, S. Ankati, Free Radicals: Implications in Etiology of Chronic Diseases and Their Amelioration through Nutraceuticals, Pharmacologia, 6 (2015) 11-20.

[23] I. Gulcin, Antioxidants and antioxidant methods: an updated overview, Archives of Toxicology, 94 (2020) 651715.

[24] K. P. Anthony, M. A. Saleh, Free radical scavenging and antioxidant activities of silymarin components, Antioxidants, 2 (2013) 398-407.

[25] J. Müller, A. Martins, J. Csábi, F. Fenyvesi, Á. Könczöl, A. Hunyadi, G. T. Balogh, BBB penetration-targeting physicochemical lead selection: ecdysteroids as chemosensitizers against CNS tumors, European Journal of Pharmaceutical Sciences, 96 (2017) 571-577.

[26] C. A. Lipinski, F. Lombardo, B. W. Dominy, P. J. Feeney, Experimental and computational approaches to estimate solubility and permeability in drug discovery and development settings, Advanced Drug Delivery Reviews, 46 (2001) 3-26.

[27] C. Aldrich, C. Bertozzi, G. I. Georg, L. Kiessling, C. Lindsley, D. Liotta, K. M. Merz, A. Schepartz, S. Wang, The ecstasy and agony of assay interference compounds, Journal of Medicinal Chemistry, 60 (2017) 2165-2168.

[28] T. Sterling, J. J. Irwin, ZINC 15-ligand discovery for everyone, Journal of Chemical Information and Modeling, 55 (2015) 2324-2337. 
Izvod

\section{SINTEZA, KARAKTERIZACIJA I PROCENA ANTIOKSIDATIVNE I ANTIMIKROBNE AKTIVNOSTI TRI NOVA N-HETEROAROMATIČNA HIDRAZONIL-TIAZOLA}

Sanja B. Kokanov ${ }^{1}$, Milan Nikolić1, Irena Novaković², Tamara R. Todorović1, Nenad R. Filipović ${ }^{3}$
(ORIGINALNI NAUČNI RAD) UDK 628.31:544.526.5

DOI $10.5937 /$ savteh2102014K
1Univerzitet u Beogradu, Hemijski fakultet, Studentski trg 12-16, 11000 Beograd, Republika Srbija
2Univerzitet u Beogradu, Institut za hemiju, tehnologiju i metalurgiju, Njegoševa 12, 11000 Beograd, Republika Srbija
3Univerzitet u Beogradu, Poljoprivredni fakultet, Nemanjina 6, 11000 Beograd, Republika Srbija

(Tiazolil-2-il)-hidrazoni (TH) su grupa organskih jedinjenja koja sadrže i hidrazon i 1,3-tiazol farmakofore koje su prisutne u mnogim odobrenim lekovima. Poslednjih godina se u velikoj meri istražuju zbog jakih antikancerogenih, antibakterijskih, antifungalnih, antituberkuloznih, antiinflamatornih i antiparazitskih aktivnosti. $U$ ovoj studiji, sintetisan je jedan novi TH na bazi piridina i dva na bazi hinolina, koji su okarakterisani elementalnom analizom, infracrvenom spektroskopijom sa Furijeovom transformacijom (FTIR) i spektroskopijom nuklearne magnetne rezonancije (NMR). Antimikrobna aktivnost jedinjenja je testirana na pet Gram-pozitivnih i pet Gram-negativnih bakterijskih sojeva, kao i na tri soja gljivica. Šest antioksidativnih testova je korišćeno za određivanje antioksidativnog kapaciteta sintetisanih jedinjenja. Rezultati su pokazali da su TH na bazi hinolina aktivniji prema testiranim Gram-negativnim sojevima bakterija i prema gljivicama, nego jedinjenja na bazi piridina. Sva jedinjenja su pokazala odlično antioksidativno dejstvo, uporedivo ili veće od korišćenih standarda (vitamin C i troloks). Parametri apsorpcije, distribucije, metabolizma, izlučivanja i toksičnosti (ADME) izračunati su in-silico. Rezultati ukazuju na dobre farmakokinetičke profile ispitivanih jedinjenja, posebno jedinjenja na bazi 2-hinolinkarboksaldehida koje ima potencijal da bude kandidat za osnovno jedinjenje (engl. lead compound).
Ključne reči: Hidrazoni, tiazoli, antibakterijsko delovanje, antifungalno delovanje, antioksidativni kapacitet, ADMET. 